\begin{tabular}{|c|c|}
\hline Title & DMSP and DMS in coastal fast ice and under-ice water of Lützow-Holm Bay, eastern A ntarctica \\
\hline Author(s) & Nomura, Daiki; Kasamatsu, Nobue; Tateyama, Kazu; Kudoh, Sakae; Fukuchi, Mitsuo \\
\hline Citation & $\begin{array}{l}\text { Continental Shelf Research, 31(13), 1377-1383 } \\
\text { https://doi.org/10.1016/.csr.2011.05.017 }\end{array}$ \\
\hline Issue Date & 2011-09-01 \\
\hline DOC URL & http:/hdl.handle.net/2115/70577 \\
\hline Rights & $\begin{array}{l}\text { (2) 2011. Inis manuscript version is made avallable under the CC-BY-IC-IVD } 4.0 \text { IIcense } \\
\text { https:/creativecommons.org/icenses/by-nc-nd/4.0/ }\end{array}$ \\
\hline Rights(URL) & https://creativecommons.org/icenses/by-nc-nd/4.0/ \\
\hline Type & article (author version) \\
\hline File Information & CSR_31_13(2011).pdf \\
\hline
\end{tabular}

Instructions for use 


\section{DMSP and DMS in coastal fast ice and under-ice water of Lützow-Holm Bay, eastern Antarctica}

Daiki Nomura $^{\mathrm{a}, *}$, Nobue Kasamatsu ${ }^{\mathrm{a}, \mathrm{b}}$, Kazu Tateyama ${ }^{\mathrm{c}}$, Sakae Kudoh $^{\mathrm{a}}$, Mitsuo Fukuchi ${ }^{\mathrm{a}}$

${ }^{a}$ National Institute of Polar Research, 10-3 Midori-cho, Tachikawa, Tokyo 190-8518, Japan.

${ }^{b}$ Present address, Tokyo University of Marine Science and Technology, 4-5-7 Konan, Minato-ku, Tokyo 108-8477, Japan.

${ }^{c}$ Kitami Institute of Technology, 165 Koen-cho, Kitami, Hokkaido 090-8507, Japan.

*Corresponding author. Tel.: +81-42-512-0764; Fax: +81-42-528-3492.

E-mail address: nomura.daiki@nipr.ac.jp or d-nomu@hotmail.co.jp (D. Nomura)

\section{ABSTRACT}

The combined concentration of total dimethylsulfoniopropionate and dimethylsulfide (DMSP+DMS) were measured in Antarctic fast ice on the coast of Lützow-Holm Bay, eastern Antarctica. High bulk-ice DMSP+DMS and chlorophyll $a$ concentrations were found at the bottom of the sea ice, and these concentrations were higher than those in the under-ice water. The bulk-ice DMSP+DMS and chlorophyll $a$ concentrations were highly correlated $\left(r^{2}=0.68, P<0.001\right)$, suggesting that the high bulk-ice DMSP+DMS concentrations were caused mainly by the presence of algae assemblages in the ice. The calculated brine DMSP+DMS concentrations were as high as $1100 \mathrm{nM}$ in the bottom ice layer, and the vertical profile patterns of brine DMSP+DMS concentrations were almost the same as for the bulk ice, mainly because of the small amount of variability in the vertical brine volume fraction. DMSP+DMS and chlorophyll $a$ concentrations in the under-ice water increased, whereas the salinity of the under-ice water decreased, during the sampling period. These results reflect the supply of freshwater containing high levels of DMSP+DMS to the water just under the ice as the ice melted. These results suggest that sea-ice 
melting could be important to sulfur cycling in coastal ice-covered regions of the polar oceans.

Keywords: Sea ice; DMSP; DMS; Ice melting; Under-ice water.

\section{Introduction}

Dimethylsulfide (DMS) is one of the most abundant volatile sulfur compounds in the ocean and accounts for up to half of the global biogenic sulfur flux to the atmosphere (Liss et al., 1997). DMS is derived mainly from dimethylsulfoniopropionate (DMSP) through enzymatic cleavage in surface waters. The ocean is a reservoir for DMS and a major source of supply of DMS to the atmosphere via the sea surface (Liss et al., 1997). Oxidation of DMS in the atmosphere produces sulfate aerosols, and the end products of DMS oxidation are major contributors to cloud condensation nuclei, which control cloud albedo and thereby influence the radiative balance of the Earth (Charlson et al., 1987). Atmospheric methane-sulfonate (MSA), a photo-oxidation product of DMS in the air, exhibits significant seasonal and long-term variations (Li et al., 1993). Recently, MSA levels in East Antarctic continental ice cores were found to be correlated with the extent of seasonal sea ice and were hypothesized to be a proxy for sea-ice extent (Curran et al., 2003).

In the polar oceans, sea ice contains larger amounts of DMS and DMSP than does the under-ice water, although the amounts in the sea ice are highly variable (Kirst et al., 1991; Levasseur et al., 1994; Turner et al., 1995; DiTullio et al., 1998; Trevena et al., 2003; Trevena and Jones, 2006; Delille et al., 2007). These high concentrations have been attributed to sea ice providing a habitat for organisms such as ice algae, which are the dominant organisms within the sea-ice brine pockets and channels (e.g. Arrigo, 2003; Lizotte, 2003). Therefore, ice melting causes elevated DMS concentrations in seawater from the release of sea ice DMS and DMSP (Kirst et al., 1991; Trevena and Jones, 2006). In addition, DMS is emitted to the atmosphere from the sea ice surface and from leads within the ice, thereby contributing to the ocean-atmosphere DMS flux in the Southern Ocean (Zemmelink et al., 2005, 2008). One of the important factors affecting the magnitude of the gas exchange between the sea ice and the atmosphere is the gas concentrations in brine channels 
(Delille, 2006; Nomura et al., 2006, 2010). However, we have only limited knowledge of brine DMSP and DMS concentrations, and particularly of the temporal variations in DMSP and DMS distributions in brine channels. More information on DMSP and DMS in sea-ice brine is needed for a better understanding of sulfur budgets and sulfur cycling in sea ice.

In this study, we measured the temporal variations in the combined concentration of total DMSP (dissolved and particulate DMSP)+DMS in the land-fast ice in Lützow-Holm Bay, off Syowa Station, Antarctica. To determine the vertical distribution of brine DMSP+DMS concentrations in sea ice with high resolution, and to understand the mechanisms controlling these concentrations in sea-ice brine, we calculated brine DMSP+DMS concentrations from bulk-ice values and the brine volume fraction.

\section{Materials and Methods}

Field observations were performed during the 48th Japanese Antarctic Research Expedition (JARE48) over fast ice in Lützow-Holm Bay off Syowa Station, Antarctica (Fig. 1). The sampling period was from 28 December 2006 to 29 January 2007. Temporal variations in physical properties (temperature, salinity, and brine volume fraction), DMSP+DMS, and chlorophyll $a$ concentration in sea ice and under-ice water were measured at a fixed sampling station $\left(68^{\circ} 59^{\prime} 53.6^{\prime \prime} \mathrm{S}, 39^{\circ} 37^{\prime}\right.$ $02.8^{\prime \prime}$ E) located approximately $2 \mathrm{~km}$ offshore from Syowa Station (water depth, $95 \mathrm{~m}$ ).

Sea ice was collected by using a SIPRE (Snow, Ice, and Permafrost Research Establishment)-type ice corer with an inside diameter of $7.5 \mathrm{~cm}$. Ice temperatures were measured by inserting a needle-type temperature sensor (D617, TechnoSeven Co., Ltd., Japan) into holes drilled into the core immediately after the ice core was collected. In order to elucidate the vertical profiles in more detail at the bottom of the sea ice, where high chlorophyll $a$ concentrations are usually found (e.g. Thomas et al., 1995), the core from the lower part of the sea ice was then cut with a stainless-steel saw into sections of 10 to $20 \mathrm{~cm}$. The core from the upper part of the sea ice was cut into 30 - to 40-cm sections. Ice sections were placed into zipper-type polyethylene bags. Ice cores were sampled within a $10 \mathrm{~m} \times 10 \mathrm{~m}$ area in order to overcome spatial heterogeneity. 
Using a hole in the sea ice made by an ice drill (Jiffy model 30, Feldmann Engineering and Manufacturing Co., Inc., USA) in the same area as the ice sampling, under-ice water was collected with a Bandon water sampler (1-L Rigo boring water bottle, 5025B, Rigosya Co., Ltd., Japan) from just below the ice and at depths of 5, 10, 15, 20,30, and $50 \mathrm{~m}$ below the surface of the sea ice. The water samples were collected approximately $15 \mathrm{~min}$ after drilling of the sea ice was completed to avoid any disturbance caused by drilling. Samples for DMSP+DMS analysis were transferred to 30 -mL serum bottles, each containing $4 \mathrm{~mL}$ of $6 \mathrm{M} \mathrm{NaOH}$. For chlorophyll $a$ measurement, under-ice water samples were placed into $300-\mathrm{mL}$ plastic bottles. Under-ice profiles of temperature and salinity were collected through the ice hole with a conductivity-temperature-depth (CTD) probe (SBE 19plus, Sea-Bird Electronics, Inc., USA).

Sea-ice samples and under-ice water samples were kept cold and in the dark in insulated boxes and transported at the end of each sampling day to the laboratory onboard the Japan Maritime Self-Defense Force icebreaker Shirase moored near East Ongul Island (Fig. 1).

\section{Sample Analysis}

Immediately on arrival in the onboard laboratory, sea-ice sections were cut with a slicer. The sliced ice was very thin $(<2 \mathrm{~mm})$ and it seemed like fine flakes. Because the serum bottles $(30-\mathrm{mL})$ used in this study were too small to contain each entire melted sea-ice section, the sliced ice was mixed with a glass rod in a polyethylene bag and then about $25 \mathrm{~cm}^{3}$ of ice was quickly put into a serum bottle containing $4 \mathrm{~mL}$ of $6 \mathrm{M} \mathrm{NaOH}$. To minimize DMS loss, these processes were completed within $5 \mathrm{~min}$. Even with a processing time of $<5 \mathrm{~min}$, some DMS loss from the slices would occurred, leading to the underestimation of the DMSP+DMS concentration in sea ice. However, it is difficult to quantify the DMS loss during a processing time. The ice that had been added to the serum bottle was then melted at $4{ }^{\circ} \mathrm{C}$. After melting the ice, the volume of headspace in the bottle was 5 to $10 \mathrm{~mL}$. The alkali treatment cleaves the DMSP, yielding gaseous DMS. Serum bottles containing the meltwater or under-ice water were stored at $4{ }^{\circ} \mathrm{C}$ for at least $24 \mathrm{~h}$ to complete the cleavage before analysis. For analysis, the serum bottles were purged with pure nitrogen gas 
(Kasamatsu et al., 2004). DMSP+DMS (as DMS) concentrations were determined on a gas chromatograph (GC-14B, Shimadzu Co. Ltd., Japan) equipped with a flame photometric detector. Calibration standards (17.0 to 208.0 nM DMS) made from pure liquid DMS by stepwise dilution with benzene were used to calibrate the gas chromatograph before and after the measurement (Kasamatsu et al., 2004). The analytical error for each measurement was 11\%.

For chlorophyll $a$ and salinity measurements, ice sections were cut in the same manner as for DMSP+DMS and then melted in polyethylene bags at room temperature in the dark shortly before analysis.

For chlorophyll $a$ measurement, meltwater and under-ice water were filtered onto 25-mm Whatman $\mathrm{GF} / \mathrm{F}$ filters. Pigments on the filters were extracted in dimethylformamide (Suzuki and Ishimaru, 1990) for $24 \mathrm{~h}$ at approximately $-80^{\circ} \mathrm{C}$. Concentrations of pigments were determined onboard the ship (Parsons et al., 1984) with a fluorometer (Model 10AU, Turner Designs, Inc., USA).

The salinities of meltwater (bulk ice) were measured with a salinity sensor (model CEH-12, Horiba, Ltd., Japan). The brine volume of sea ice was calculated from the ice temperature and bulk-ice salinity, as described by Cox and Weeks (1983) for temperatures below $-2{ }^{\circ} \mathrm{C}$ and by Leppäranta and Manninen (1988) for temperatures from $0{ }^{\circ} \mathrm{C}$ to $-2{ }^{\circ} \mathrm{C}$.

\section{Results and Discussion}

\subsection{Physical parameters of sea ice}

Air temperature was almost continuously below $0{ }^{\circ} \mathrm{C}$ before the start of our sampling period, but it exceeded $0{ }^{\circ} \mathrm{C}$ during part of the period (Fig. 2). Our sampling period was during the season of maximum temperatures at Syowa Station (Japan Meteorological Agency; http://www.data.jma.go.jp/obd/stats/etrn/index.php; in Japanese). Ice temperatures were higher at the upper surface of the sea ice than in the middle or at the bottom of the sea ice, and they varied with air temperature and increased with time (Fig. 3a), suggesting that the ice was melting during 
this period.

Sea-ice thickness and snow depth are shown in Table 1. Sea-ice thickness was almost constant, ranging from 1.69 to $2.01 \mathrm{~m}$ with an average $( \pm \mathrm{SD})$ of $1.90 \mathrm{~m}( \pm 0.13 \mathrm{~m})$ (Table 1). However, the depth of snow deposited over the sea ice decreased as the snow melted because of the increase in air temperature. The sea ice collected during the period was typical of the fast ice in Lützow-Holm Bay (Kawamura et al., 1997). Kawamura et al. (1997) reported that the formation of snow ice and of ice superimposed over sea ice is an important sea-ice growth process in this area. Snow ice is formed by the flooding of sea ice by seawater and subsequent freezing of the snow and water (Lange et al., 1990; Jeffries et al., 2001). Superimposed ice is formed by snow melting and refreezing on the sea-ice surface (Eicken et al., 2004). This is likely one of reasons why we did not observe a decrease in sea-ice thickness even though our sampling was done during the melting season. The low bulk-ice salinity at the top of the sea ice (Fig. 3b) reflects surface melting and the formation of snow ice and superimposed ice during this period. No slush layer (gap layer) was detected over the sea ice. The brine volume exceeded 5\% throughout the entire thickness of the sea ice, except in the top layers of sea ice collected on 28 December 2006 and 28 January 2007 (Fig. 3c), indicating that there was a high level of permeation of brine in the brine channel network (Golden et al., 1998).

\subsection{Biogeochemical parameters of sea ice}

We examined the profiles of the bulk-ice DMSP+DMS and chlorophyll $a$ concentrations in the sea ice. Bulk-ice DMSP+DMS concentrations were higher (up to $110 \mathrm{nM}$ ) in the bottom parts of the sea ice than in the middle or upper parts (Fig. 3d). Bulk-ice chlorophyll $a$ concentrations were high (up to $239.3 \mu \mathrm{g} \mathrm{L}^{-1}$ ) in the bottom layer of sea ice (Fig. 3e).

High bulk-ice DMSP concentrations have previously been found in Arctic and Antarctic sea ice (e.g. Levasseur et al., 1994; Trevena and Jones, 2006). Trevena and Jones (2006) reported that bulk-ice DMSP concentrations ranged from 25 to $796 \mathrm{nM}$ in Antarctic pack and fast ice. In contrast, extremely high bulk-ice DMSP concentrations (up to 13,500 nM) were found in Antarctic rafted ice (Trevena and Jones, 2006). These high bulk-ice DMSP concentrations have been attributed mostly to the presence of algal assemblages within the sea ice (Kirst et al., 1991; Trevena and Jones, 2006). 
To elucidate the factors controlling the distribution of DMSP+DMS in sea ice, we examined the relationship between bulk-ice DMSP+DMS and bulk-ice chlorophyll $a$ concentrations (Fig. 4). As expected, this relationship showed a high correlation $\left(r^{2}=0.68, P<0.001\right)$, since high bulk-ice DMSP+DMS concentrations are produced by algae within the sea ice. The same relationship between chlorophyll $a$ and DMSP has been found in Antarctic rafted sea ice (Trevena and Jones, 2006). These high DMSP concentrations have been attributed to the presence of a large biomass of algae (Trevena and Jones, 2006). DMSP production within marine algal cells contributes to protection from osmotic damage (e.g., Dickson and Kirst, 1986).

\subsection{Brine DMSP $+D M S$ and chlorophyll a concentration}

The extensive brine channel system in sea ice provides a habitat for organisms such as ice algae, which are the dominant inhabitants of the brine pockets and channels (e.g., Arrigo, 2003; Lizotte, 2003). Chemical components such as DMSP and DMS are also found in sea-ice brine; therefore, it is important to know their distribution within the brine channels. However, it is difficult to collect the brine directly from each ice layer with high resolution, particularly during the ice-melting season (McMinn et al., 2009; Nomura et al., 2009). Therefore, we used the following approach to help understanding the processes occurring in the sea-ice brine channels.

DMSP+DMS concentrations in brine within brine channels were calculated from the measured bulk-ice concentrations and the brine volume fraction of each ice layer. The equation for the DMSP+DMS calculation is:

$\left[D M S P+D M S_{\text {brine }}\right]=\left[D M S P+D M S_{\text {bulk-ice }}\right] / F_{\text {brine }}$

where $\left[D M S P+D M S_{\text {brine }}\right]$ is the brine DMSP+DMS concentration, $\left[D M S P+D M S_{\text {bulk-ice }}\right]$ is the bulk-ice DMSP+DMS concentration, and $F_{\text {brine }}$ is the brine volume fraction.

We calculated the vertical profiles of brine DMSP+DMS concentrations (Fig. 5). The patterns of these profiles were almost the same as for the bulk-ice DMSP+DMS (Fig. 3d) owing to the small 
vertical variability of the brine volume fraction (Fig. 3c). DMSP+DMS concentrations of approximately $100 \mathrm{nM}$ were calculated at the top of the ice. The average $( \pm \mathrm{SD})$ concentration of brine DMSP+DMS was calculated as $332.4 \mathrm{nM}( \pm 247.5 \mathrm{nM})$, which was much higher than that of the under-ice water (see Fig. 6c). The brine DMSP+DMS concentration was higher at the bottom of the sea ice than at the top (Fig. 5). High DMSP+DMS concentrations (up to $1100 \mathrm{nM}$ ) were calculated in the bottom parts of the sea ice on 28 December 2006. These results suggest that the bottom layers of sea ice are a source of the DMSP+DMS in the middle and upper layers owing to upward transport (flushing) of DMSP+DMS by molecular diffusion and tidal mixing through the well-developed brine channels (Fig. 3c) (Hudier et al., 1995; Nomura et al., 2009).

\subsection{Physical and biogeochemical parameters of under-ice water}

We examined the vertical profiles of temperature, salinity, and DMSP+DMS and chlorophyll $a$ concentrations in the under-ice water (Fig. 6). The temperature of the upper part of the under-ice water (above about $20 \mathrm{~m}$ ) increased during the study period (Fig. 6a). In particular, the temperature just below the ice (about $2 \mathrm{~m}$ ) increased from $-1.6^{\circ} \mathrm{C}$ on 28 December 2006 to $-1.1{ }^{\circ} \mathrm{C}$ on 29 January 2007. However, the water column temperature below $20 \mathrm{~m}$ depth was almost constant at $-1.7 \pm 0.03{ }^{\circ} \mathrm{C}$ (average $\pm \mathrm{SD}$ ). In contrast to temperature, the salinity just below the ice decreased dramatically during the study period, from 34.0 on 28 December 2006 to 19.4 on 8 January 2007. The water column salinity below $10 \mathrm{~m}$ was almost constant at $34.1 \pm 0.03$.

Our results reflect the supply of freshwater to the water just under the ice because of ice melting. The ice temperature increased with increasing air temperature during the study period (Figs. 2 and 3a). As a result of the ice warming (Fig. 3a), meltwater in the brine channel network was released to the under-ice water. The reduction in bulk-ice salinity during the study period supports the internal melting and release of meltwater (Fig. 3b), although a decrease in ice thickness was not observed (Table 1). The presence of a cover of sea ice over the sea surface increases the water column stability because surface mixing by wind forcing is restricted (Granskog et al., 2005). We therefore suggest that the variations in temperature and salinity in the water just under the ice were most likely caused by the supply of freshwater from ice-melting. Although an under-ice river-water plume can transport freshwater (e.g. Granskog et al., 2005; Nomura et al., 2009), there is no river 
near our sampling area (Fig. 1). Previous oceanographic observations in Lützow-Holm Bay by Ohshima et al. (1996) indicate that runoff of meltwater from the continent is a minor component of the freshening. They also indicate that the most plausible mechanisms for the under-ice freshening are freshwater advection from offshore that accumulates in the coastal region, and meltwater supply from sea ice.

The variations in DMSP+DMS and chlorophyll $a$ concentrations in the under-ice water were similar, and the concentrations of both increased substantially in the upper layer of under-ice water (above $15 \mathrm{~m}$ ) during the study period (Fig. 6c and d). The DMSP+DMS concentration just under the ice increased from $5.4 \mathrm{nM}$ on 28 December 2006 to $48.6 \mathrm{nM}$ on 29 January 2007 (Fig. 6c).

DMSP+DMS concentrations in the water column below $15 \mathrm{~m}$ were almost constant at $3.9 \pm 2.0 \mathrm{nM}$. Chlorophyll $a$ concentrations just under the ice increased from $0.23 \mu \mathrm{g} \mathrm{L}^{-1}$ on 28 December 2006 to $2.86 \mu \mathrm{g} \mathrm{L}^{-1}$ on 29 January 2007, whereas the concentrations below $30 \mathrm{~m}$ were almost constant at $0.11 \pm 0.09 \mu \mathrm{g} \mathrm{L}^{-1}$ (Fig. 6d). The chlorophyll $a$ concentrations just under the ice and below $30 \mathrm{~m}$ were coincident with the values previously obtained in the same area and season (Ichinoimiya et al., 2007).

DMSP+DMS concentrations in bulk-ice at the bottom of the sea ice were high, at up to $110.4 \mathrm{nM}$ on 28 December 2006, or approximately 20 times the concentrations in water just under the ice on the same date $(5.4 \mathrm{nM})$ (Figs. $3 \mathrm{~d}$ and $6 \mathrm{c}$ ). This suggests that melting of sea ice is a potential source of DMSP+DMS in the under-ice water. Therefore, the combined effects of in situ production of DMSP+DMS in the under-ice water by algae and the input of DMSP+DMS from melting sea ice would increase the water-column DMSP+DMS concentrations (Figs. 3d, 6c and 6d). Previous studies have shown that the release of large amounts of DMSP to the under-ice water during the ice-melting season produces high concentrations of DMSP (e.g., Trevena and Jones, 2006). These results provide supporting evidence that elevated DMSP+DMS levels in seawater contribute to the high DMS concentrations.

5. Conclusions 
We examined the DMSP+DMS concentrations in the fast ice in Lützow-Holm Bay, off Syowa Station, Antarctica, during the ice melting season. High concentrations of bulk-ice DMSP+DMS and chlorophyll $a$ were found at the bottom of the sea ice, and these concentrations were higher than those of the under-ice water. The bulk-ice DMSP+DMS and chlorophyll $a$ concentrations were highly correlated $\left(r^{2}=0.68, P<0.001\right)$, suggesting that the high bulk-ice DMSP+DMS concentration was caused mainly by the presence of algae assemblages within the sea ice.

To determine the vertical distribution of brine DMSP+DMS concentrations with high resolution in sea ice, and to elucidate the processes controlling these concentrations in sea-ice brine, we calculated the brine DMSP+DMS concentrations from bulk-ice values and brine volume fractions. The calculated brine DMSP+DMS concentrations were high (up to $1100 \mathrm{nM}$ ) in the bottom ice layer, and the vertical profile patterns of the brine DMSP+DMS concentrations were almost the same as those in the bulk ice, mainly because of the small vertical variability of the brine volume fraction.

DMSP+DMS and chlorophyll $a$ concentrations in the under-ice water increased, whereas the salinity of the under-ice water decreased, during the study period. These results reflect the supply of freshwater with a high DMSP+DMS concentration to the water just under the ice because of ice melting. The results suggest that sea ice melting is important to sulfur cycling in the coastal ice-covered regions of the polar oceans.

Acknowledgements

We sincerely thank Professor T. Odate, Dr. T. Iida, and all the members of the 48th Japanese Antarctic Research Expedition (JARE-48) for their support in the field work and for their useful comments.

\section{References}


Arrigo, K.R., 2003. Primary production in sea ice, in: Thomas, D.N., Dieckmann, G.S. (Eds), Sea Ice-an Introduction to its Physics, Chemistry, Biology and Geology. Blackwell Science, Oxford, pp. 143-183.

Charlson, R.J., Lovelock, J.E., Andreae, M.O., Warren, S.G., 1987. Oceanic phytoplankton, atmospheric sulphur, cloud albedo and climate. Nature 326, 655-661.

Cox G.F.N., Weeks, W.F., 1983. Equations for determining the gas and brine volumes in sea-ice samples. J Glaciol. 29, 306-316.

Curran, M.A.J., van Ommen, T.D., Morgan, V.I., Phillips, K.L., Palmer, A.S., 2003. Ice core evidence for Antarctic sea ice decline since the 1950s. Science 302, 120, doi:10.1126/science.1087888.

Delille, B., 2006. Inorganic carbon dynamics and air-ice-sea $\mathrm{CO}_{2}$ fluxes in the open and coastal waters of the Southern Ocean. PhD thesis, University of Liége, Belgium, 297 pp.

Delille, B., Jourdain, B., Borges, A.V., Tison, J.-L. Delille, D., 2007. Biogas $\left(\mathrm{CO}_{2}, \mathrm{O}_{2}\right.$, dimethylsulfide) dynamics in Spring Antarctic fast ice. Limnol. Oceanogr. 52, 4, 1367-1379.

Dickson, D.M.J., Kirst, G.O., 1986. The role of DMSP, glycine betaine and homarine in the osmoacclimation of Platymonas subcordiformis. Planta 167, 536-543.

DiTullio, G.R., Garrison, D.L., Mathot, S., 1998. Dimethylsulfoniopropionate in sea ice algae from the Ross Sea polynya. Antarctic sea ice biological processes, interactions, and variability. Antarct. Res. Series 73, 139-146.

Eicken, H., Grenfell, T.C., Perovich, D.K., Richter-Menge, J.A., Frey, K., 2004. Hydraulic controls of summer Arctic pack ice albedo. J. Geophys. Res. 109, C08007. doi:10.1029/2003JC001989.

Golden, K.M., Ackley, S.F., Lytle, V.I., 1998. The percolation phase transition in sea ice. Science 
Granskog, M.A., Ehn, J., Niemela, M., 2005. Characteristics and potential impacts of under-ice river plume in the seasonally ice-covered Bothnian Bay (Baltic Sea). J. Mar. Sys. 53, 187-196.

Hudier, E.J.J., Ingram, R.G., Shirasawa, K., 1995. Upward flushing of sea water through first-year ice. Atmos. Ocean 33 (3), 569-580.

Ichinomiya, M., Honda, M., Shimoda, H., Saito, K., Odate, T., Fukuchi, M., Taniguchi, A., 2007. Structure of the summer under fast ice microbial community near Syowa Station, eastern Antarctica. Polar Biol. 30, 1285-1293.

Jeffries, M.O., Krouse, H.R., Hurst-Cushing, B., Maksym, T. 2001. Snow-ice accretion and snow-cover depletion on Antarctic first-year sea-ice floes. Ann. Glaciol. 33, 51-60.

Kasamatsu, N., Kawaguchi, S., Watanabe, S., Odate, T., Fukuchi, M., 2004. Possible impacts of zooplankton grazing on dimethylsulfide production in the Antarctic Ocean. Can. J. Fish. Aquat. Sci. $61,736-743$.

Kawamura, T., Ohshima, K.I., Takizawa, T., Ushio. S., 1997. Physical, structural and isotopic characteristics and growth processes of fast sea ice in Lützow-Holm Bay, Antarctica. J. Geophys. Res. 102 (C2), 3345-3355.

Kirst, G.O., Thiel, C., Nothnagel, J., Wanzek, M., Ulmke, R., 1991. Dimethylsulphoniopropionate (DMSP) in ice-algae and its possible biological role. Mar. Chem. 35, 381-388.

Lange, M.A., Schlosser, P., Ackley, S.F., Wadhams, P., Dieckmann, G.S. 1990. ${ }^{18}$ O concentrations in sea ice of the Weddell Sea, Antarctica. J. Glaciol. 36, 124, 315-323.

Leppäranta, M., Manninen, T., 1988. The brine and gas content of sea ice with attention to low salinities and high temperatures. Finnish Inst. Marine Res. Internal Rep. 88-2, Helsinki. 
Levasseur, M., Gosselin, M., Michaud, S., 1994. A new source of dimethylsulfide (DMS) for the arctic atmosphere: ice diatoms. Mar. Biol. 121, 381-387.

Li, S.M., Barrie, L.A., Sirois, A., 1993. Biogenic sulfur aerosol in the arctic troposphere: 2. Trends and seasonal variations. J. Geophys. Res. 98(D11), 20623-20631.

Liss, P.S., Hatton, A.D., Malin, G., Nightingale, P.D., Turner, S.M., 1997. Marine sulphur emissions. Philos. Trans. R. Soc. Lond., 352, 159-169.

Lizotte, M.P., 2003. The microbiology of sea ice, in: Thomas, D.N. and Dieckmann, G.S. (Eds), Sea Ice - an Introduction to its Physics, Chemistry, Biology and Geology. Blackwell Science, Oxford, pp. 184-210.

McMinn, A., Gradinger, R., Nomura, D., 2009. Biogeochemical properties of sea ice, in: Eicken, H., Gradinger, R., Salganek, M., Shirasawa, K., Perovich, D.K., Leppäranta, M. (Eds), Field Techniques for Sea Ice Research. University of Alaska Press, Fairbanks, Alaska, pp. 259-282.

Nomura, D., Inoue, Y.H., Toyota, T., 2006. The effect of sea ice growth on air-sea $\mathrm{CO}_{2}$ flux in a tank experiment. Tellus 58B, 418-426.

Nomura, D., Takatsuka, T., Ishikawa, M., Kawamura, T., Shirasawa, K., Inoue, H.Y., 2009. Transport of chemical components in sea ice and under-ice water during melting in the seasonally ice-covered Saroma-ko Lagoon, Hokkaido, Japan. Est. Coast. Shelf Sci. 81, 201-209.

Nomura, D., Inoue, Y.H., Toyota, T., Shirasawa, K., 2010. Effects of snow, snow-melting and re-freezing on air-sea ice $\mathrm{CO}_{2}$ flux. J. Glaciol. 56, 196, 262-270.

Ohshima, K.I., Takizawa, T., Ushio, S., Kawamura, T., 1996. Seasonal variations of the Antarctic coastal ocean in the vicinity of Lützow-Holm Bay. J. Geophys. Res. 101, 20617-20628.

Parsons, T.R., Takahashi, M., Hargrave, B., 1984. Biological Oceanographic Processes. Pergamon Press, Oxford, 3rd ed, 330 pp. 
Suzuki, R., Ishimaru, T., 1990. An improved method for the determination of phytoplankton chlorophyll using N,N-dimethylformamide. J. Oceanogr. 46, 190-194.

Thomas, D.N., Lara, R. J., Eicken, H., Kattner, G., Skoog, A., 1995. Dissolved organic matter in Arctic multi-year sea ice during winter: major components and relationships to ice characteristics. Polar Biol., 15, 477-483.

Trevena, A.J., Jones, G.B., 2006. Dimethylsulphide and dimethylsulphoniopropionate in Antarctic sea ice and their release during sea ice melting. Mar. Chem. 98, 210-222.

Trevena, A.J., Jones, G.B., Wright, S.W., Van den Enden, R.L., 2003. Profiles of dimethylsulphoniopropionate (DMSP), algal pigments, nutrients and salinity in the fast ice of Prydz Bay, Antarctica. J. Geophys. Res. 108, 3145-3156.

Turner, S.M., Nightingale, P.D., Broadgate, W. Liss, P.S., 1995. The distribution of dimethylsulphide and dimethylsulphoniopropionate in Antarctic waters and sea-ice. Deep-Sea Res. II 42, 1059-1080.

Zemmelink, H.J., Houghton, L., Frew, N.M., Dacey, J.W.H., 2005. Gradients in dimethylsulfide, dimethylsulfoniopropionate, dimethylsulfoxide, and bacteria near the sea surface. Mar. Ecol. Prog. Ser., 295, 33-42.

Zemmelink, H.J., Hintsa, E.J., Houghton, L., Dacey, J.W.H., Liss, P.S., 2008. DMS fluxes over the multi-year ice of the western Weddell Sea. Geophys. Res. Lett. 35, L06603, doi:10.1029/2007GL031847.

List of Tables

Table 1. Ice sampling dates, sea-ice thickness, and snow depth. 
Figure Captions

Fig. 1. Location of the sampling station in Lützow-Holm Bay, near Syowa Station, Antarctica. A fixed sampling station $\left(68^{\circ} 59^{\prime} 53.6^{\prime \prime} \mathrm{S}, 39^{\circ} 37^{\prime} 02.8^{\prime \prime} \mathrm{E}\right)$ was located approximately $2 \mathrm{~km}$ offshore from Syowa Station. Water depth at the station was $95 \mathrm{~m}$. The laboratory was onboard the Japan Maritime Self-Defense Force icebreaker Shirase, which was moored near East Ongul Island.

Fig. 2. Time series of air temperature at Syowa Station (Japan Meteorological Agency; http://www.data.jma.go.jp/obd/stats/etrn/index.php; in Japanese). Shaded area indicates the sampling period. Horizontal dashed line indicates air temperature $=0{ }^{\circ} \mathrm{C}$.

Fig. 3. Vertical profiles of (a) ice temperature, (b) bulk-ice salinity, (c) brine volume fraction, (d) bulk-ice DMSP+DMS concentration, and (e) bulk-ice chlorophyll a concentration on 28 December (open circles), 30 December (open triangles), 8 January (open squares), 18 January (crosses), and 28 January (open diamonds). Legend indicates the symbols for each sampling date.

Fig. 4. Relationship between log-transformed bulk-ice DMSP+DMS and chlorophyll $a$ concentrations during the study period. Dashed line indicates the fitting curve used to describe the relationship.

Fig. 5. Vertical profiles of calculated DMSP+DMS concentrations in brine on 28 December (open circles), 30 December (open triangles), 8 January (open squares), 18 January (crosses), and 28 January (open diamonds). Legend indicates the symbols for each sampling date.

Fig. 6. Vertical profiles of (a) temperature, (b) salinity, (c) DMSP+DMS, and (d) chlorophyll a concentrations in under-ice water for 28 December (open circles), 30 December (open triangles), 8 January (open squares), 18 January (crosses), and 29 January (open diamonds). Legend indicates the symbols for each sampling date. Data on temperature and salinity were collected through the ice hole with a conductivity-temperature-depth probe. Samples for DMSP+DMS and chlorophyll $a$ 
concentration analysis were collected just below the sea ice and at depths of $5,10,15,20,30$, and $50 \mathrm{~m}$ below the ice surface. 


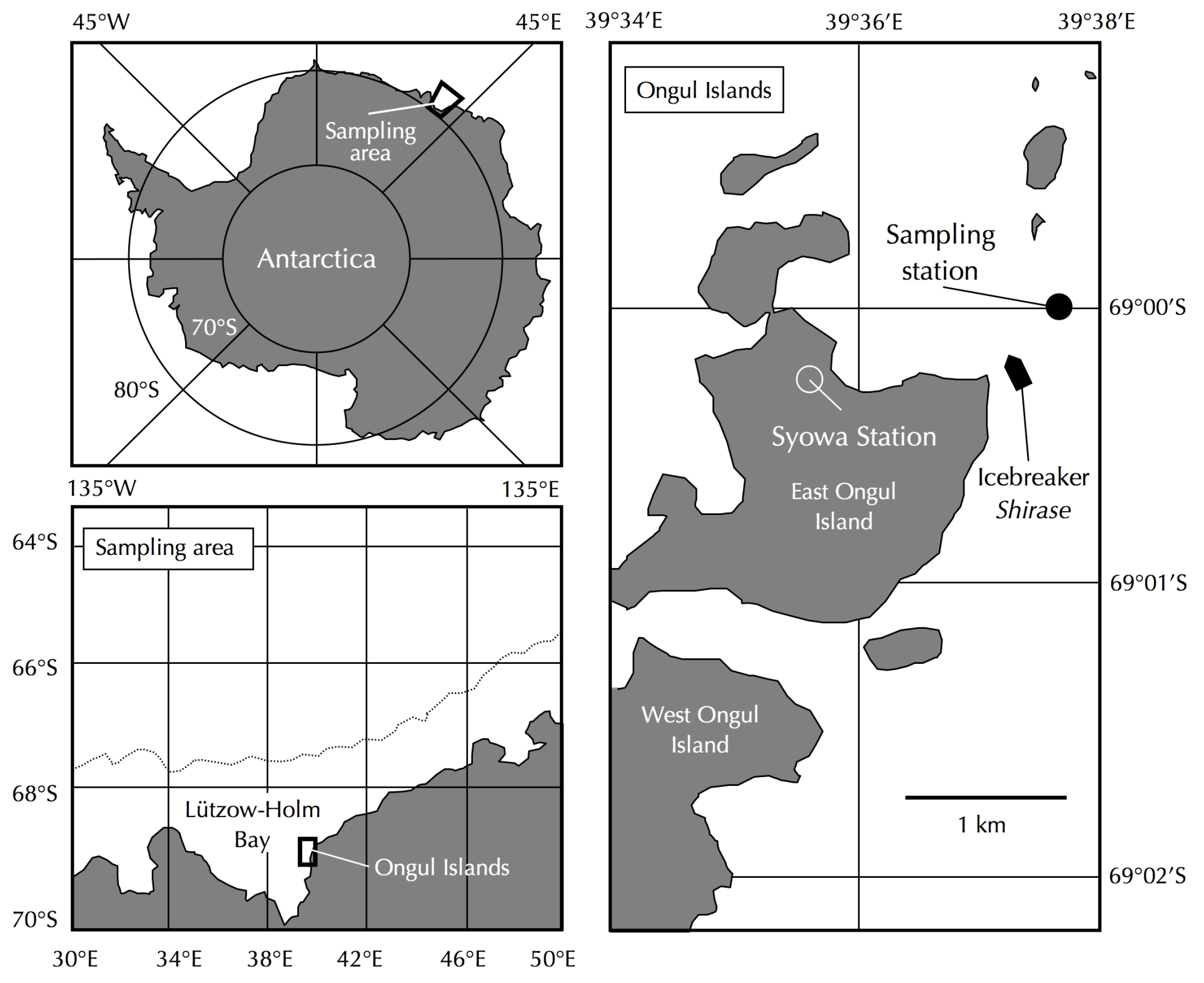

Nomura et al., Fig. 1 


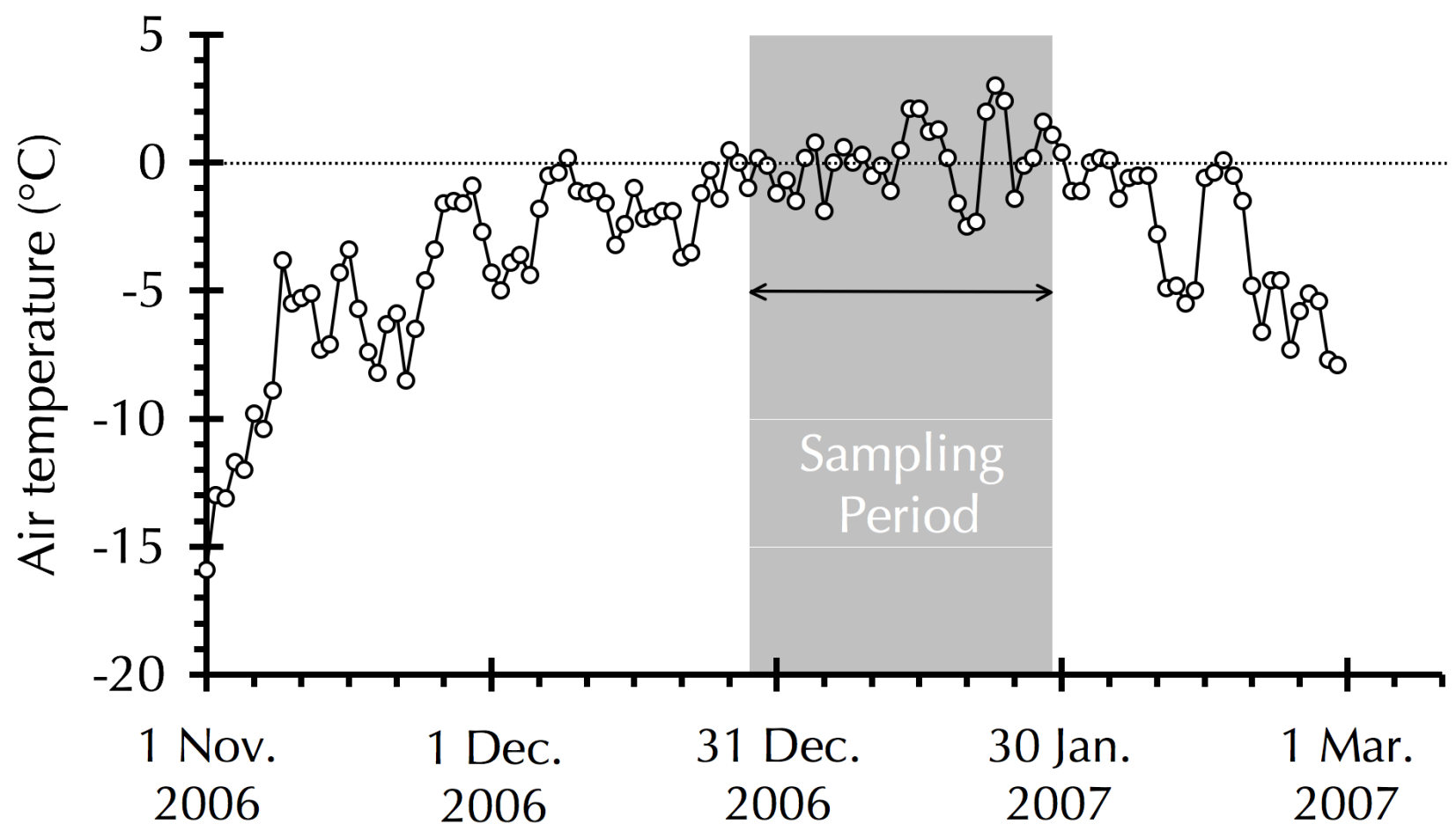

Nomura et al., Fig. 2 


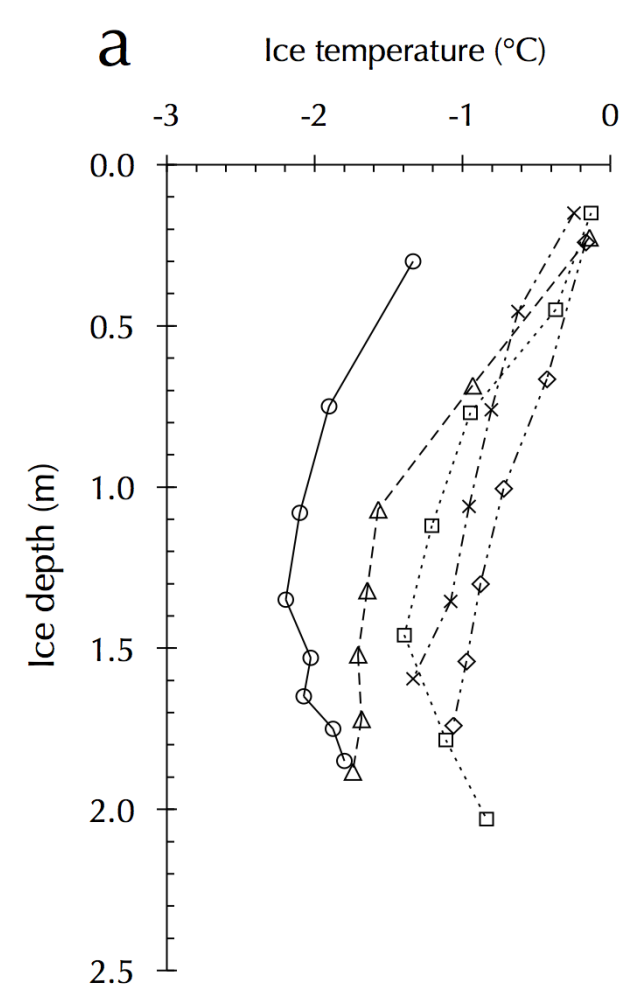

b Bulk-ice salinity

C Brine volume (\%)
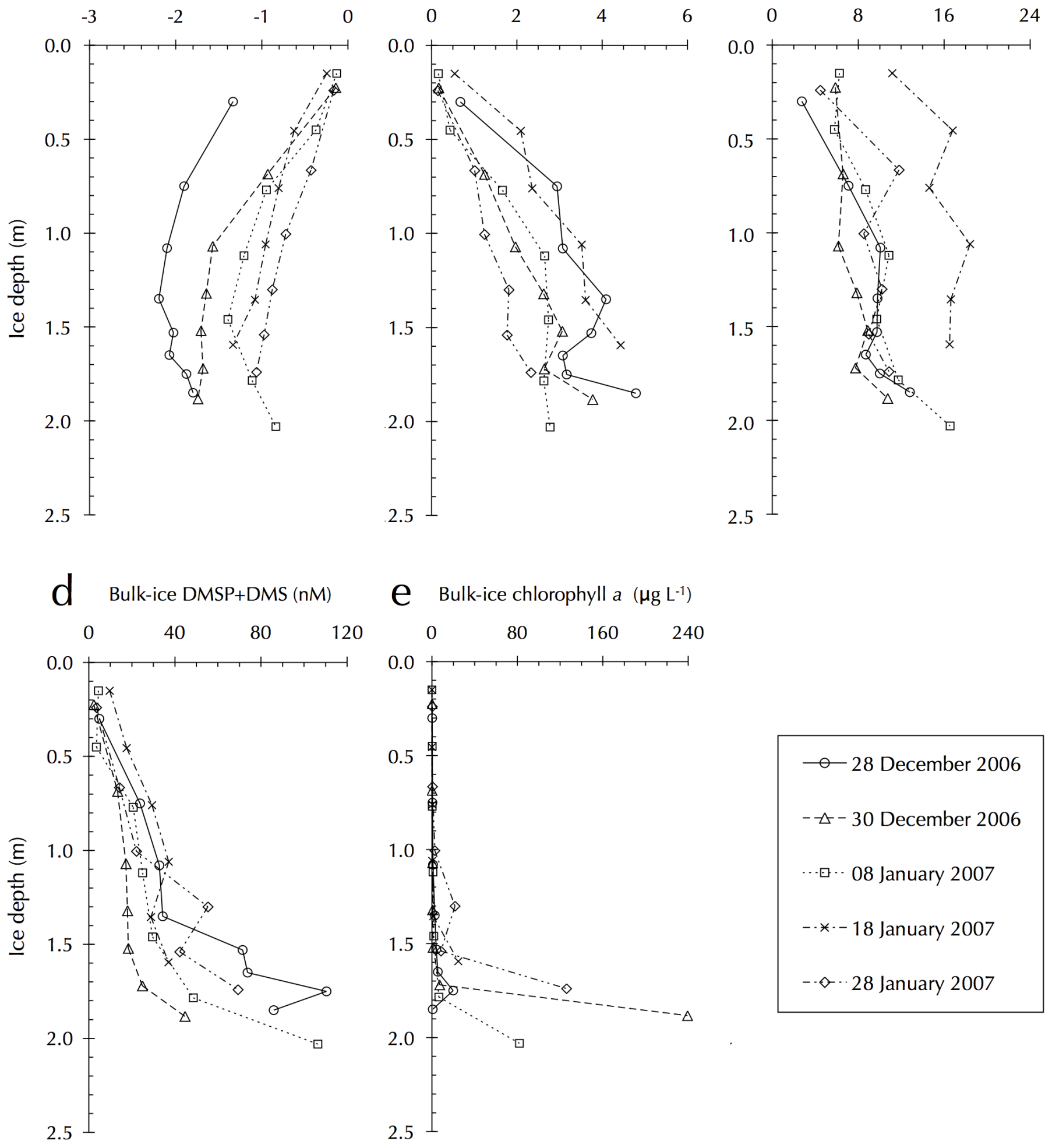

e Bulk-ice chlorophyll a $\left(\mu \mathrm{g} \mathrm{L}^{-1}\right)$

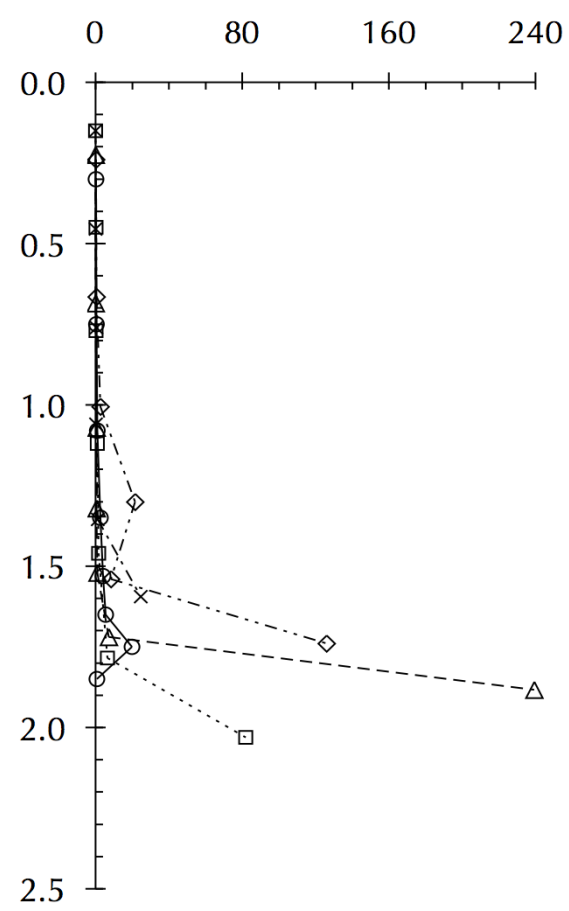

—— 28 December 2006

$-\triangleleft-30$ December 2006

$\cdots \cdot 08$ January 2007

-**-- 18 January 2007

$-\diamond \cdots 28$ January 2007 


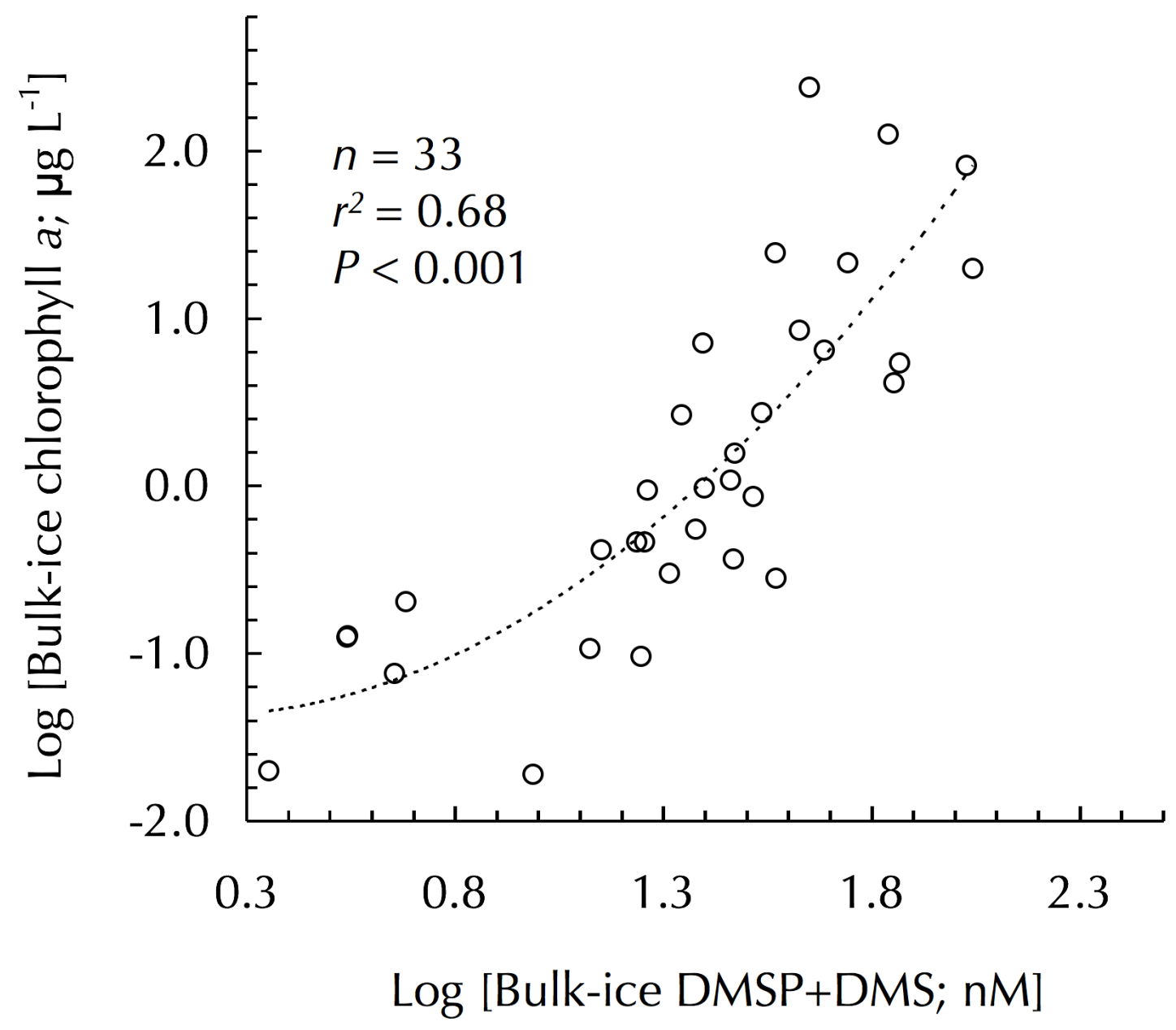

Nomura et al., Fig. 4 


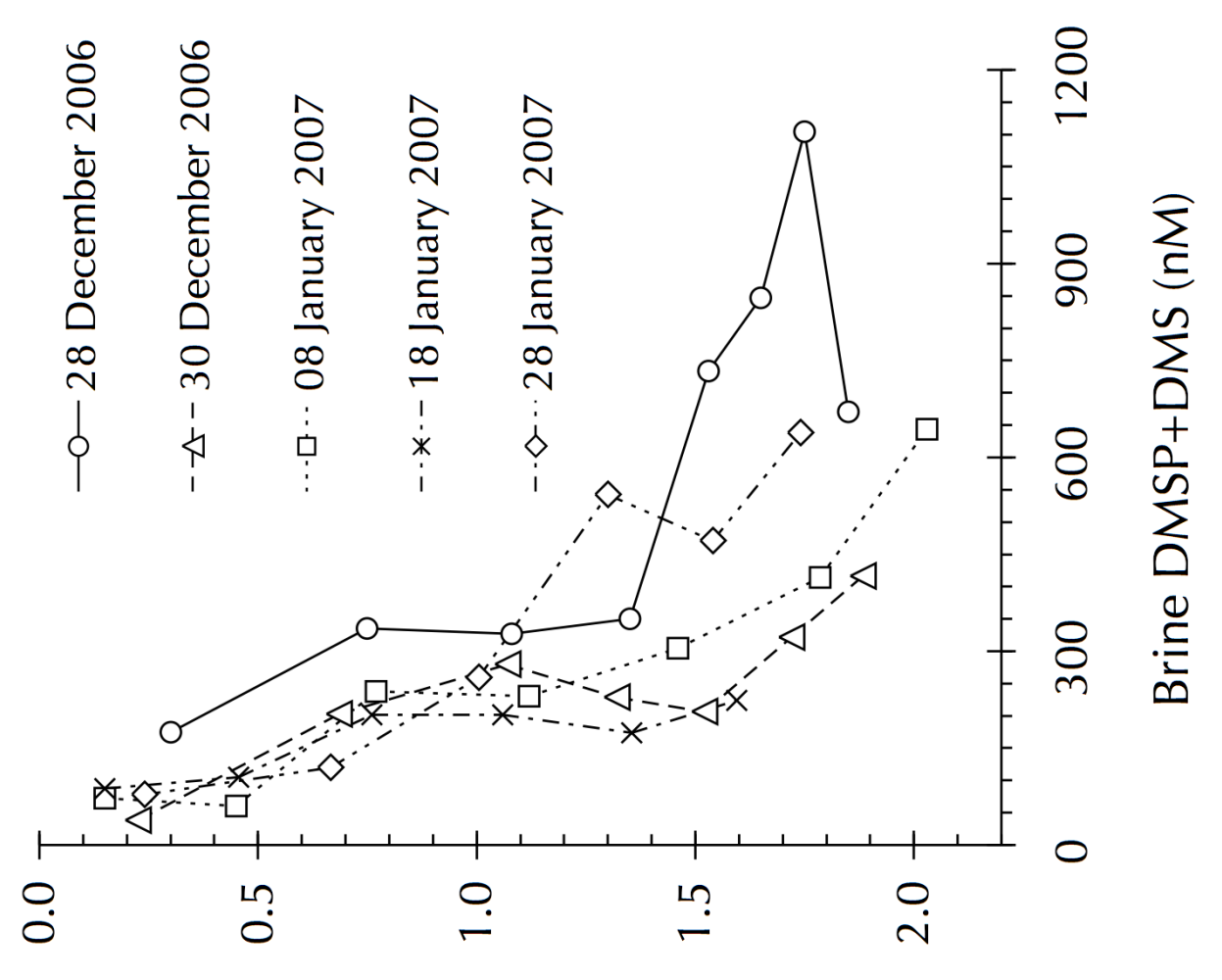

(u) yłdap әэ

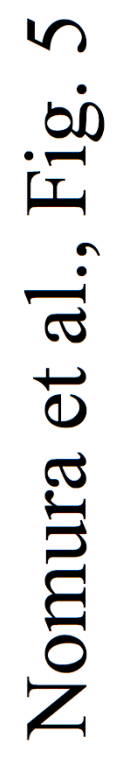




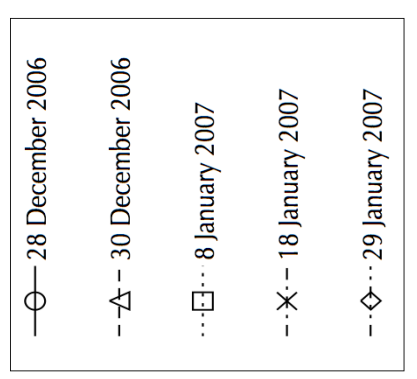

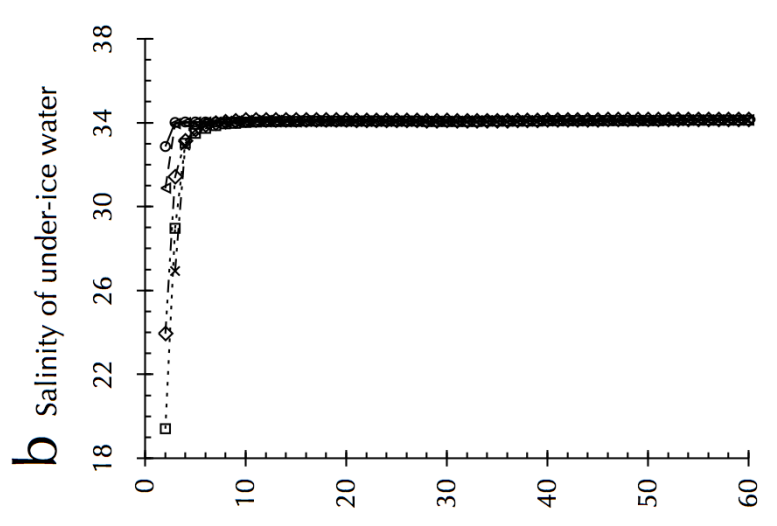

(w) чұdәр дәтем

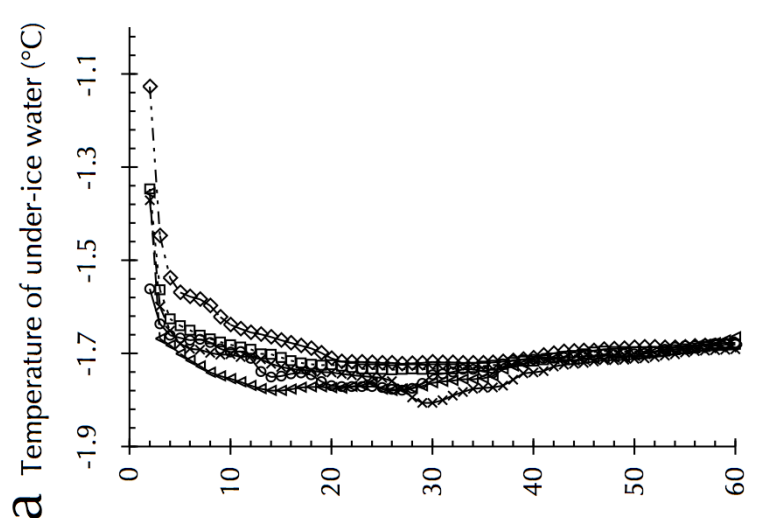

(u) чıдәр дәғем
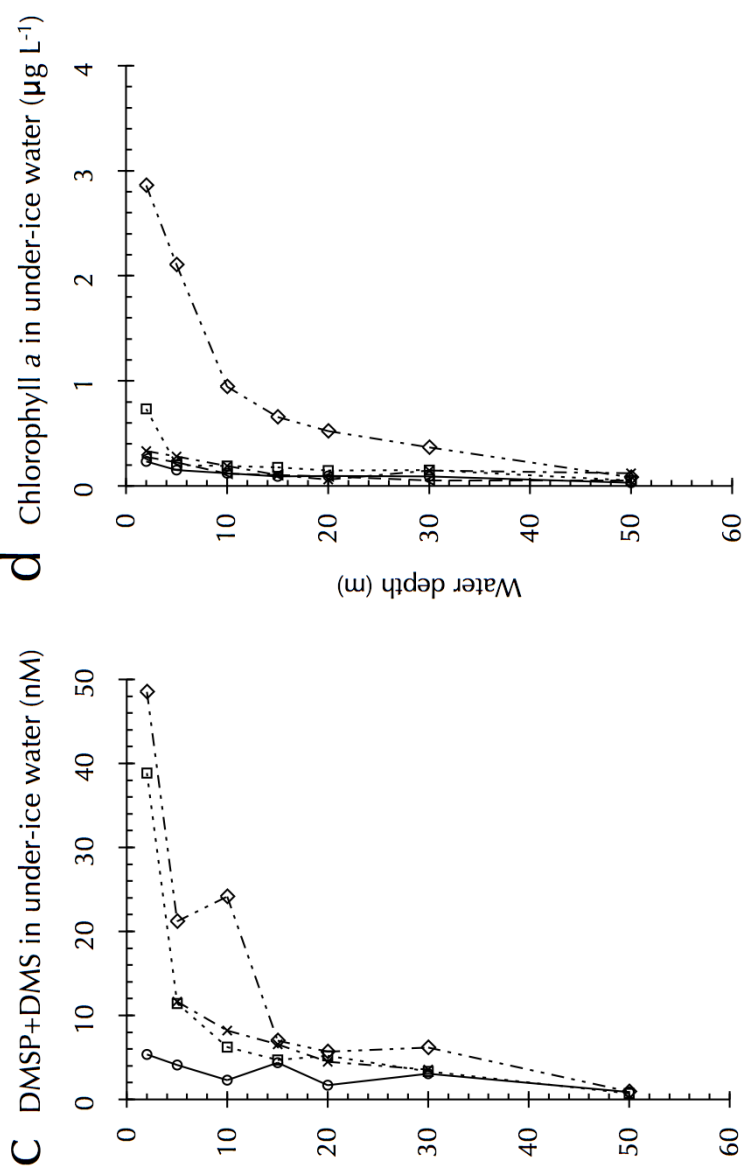

(u) чұdәр дәңем 
Table 1

Ice sampling dates, sea-ice thickness, and snow depth.

\begin{tabular}{ccc}
\hline Date & Sea-ice thickness & Snow depth \\
$\mathrm{m}$ & $\mathrm{m}$ \\
\hline 28 December 2006 & 1.98 & 0.14 \\
30 December 2006 & 1.96 & 0.07 \\
8 January 2007 & 2.01 & 0.04 \\
18 January 2007 & 1.69 & 0.02 \\
28 January 2007 & 1.84 & 0.06 \\
\hline
\end{tabular}

Nomura et al., Table 1 